\title{
THE EFFECT OF LEVERAGE, BOARD OF DIRECTORS, AUDIT COMMITTEE AND COMPANY SIZE ON THE LEVEL OF HEALTH FINANCIAL PERFORMANCE
}

\author{
Martiana Riawati Utami \\ Accounting Study Program Yogyakarta State University \\ marriawati.utami@gmail.com \\ Dr. Denies Priantinah, S.E., M.Si., Ak., CA. \\ Lecturer of Accounting Education Department Yogyakarta State University \\ denies_priantinah@uny.ac.id
}

\begin{abstract}
The Effect Of Leverage, Board Of Directors, Audit Committee And Company Size On The Level Of Health Financial Performance. This research aims to analyze (1) the effect of Leverage on the Level of Health Financial Performance, (2) the effect of Board of Directors on the Level of Health Financial Performance, (3) the effect of Audit Committee on the Level of Health Financial Performance, (4) the effect of Company Size on the Level of Health Financial Performance, and (5) the effect of Leverage, Board of Directors, Audit Committee and Company Size simultaneously on the Level of Health Financial Performance. This research was a causal research. The population of this research are manufacturing companies listed in Indonesia Stock Exchange period 2014-2016. A purposive sampling method was used as a sampling method and 96 companies were selected as sample of research. The data analysis techniques were simple linear regression analysis and multiple linear regression analysis. The result of this research indicates that (1) Leverage has a positive effect on the Level of Health Financial Performance, (2) Board of Directors has a positive effect on the Level of Health Financial Performance, (3) Audit Committee has a positive effect on the Level of Health Financial Performance, (4) Company Size has a positive effect on the Level of Health Financial Performance, and (5) Leverage, Board of Directots, Audit Committee and Company Size simultaneously has a positive effect on the Level of Health Financial Performance.
\end{abstract}

Keywords: Level of Health Financial Performance, Leverage, Board of Directors, Audit Committee, Company Size

\begin{abstract}
Abstrak : Pengaruh Leverage, Dewan Direksi, Komite Audit Dan Ukuran Perusahaan Terhadap Tingkat Kesehatan Keuangan Perusahaan . Penelitian ini bertujuan untuk mengetahui (1) pengaruh Leverage terhadap Tingkat Kesehatan Keuangan, (2) pengaruh Dewan Direksi terhadap Tingkat Kesehatan Keuangan, (3) pengaruh Komite Audit terhadap Tingkat Kesehatan Keuangan, (4) pengaruh Ukuran Perusahaan terhadap Tingkat Kesehatan Keuangan, dan (5) pengaruh Leverage, Dewan Direksi, Komite Audit dan Ukuran Perusahaan secara bersama-sama terhadap Tingkat Kesehatan Keuangan. Penelitian ini termasuk dalam penelitian hubungan kausal. Populasi penelitian ini adalah perusahaan manufaktur yang terdaftar di Bursa Efek Indonesia periode 2014-2016. Penentuan sampel menggunakan metode purposive sampling. Terdapat 96 perusahaan yang memenuhi kriteria sebagai sampel penelitian. Teknik analisis data yang digunakan adalah analisis regresi linear sederhana dan analisis regresi linear berganda. Hasil penelitian ini menunjukkan bahwa (1) Leverage berpengaruh positif terhadap Tingkat Kesehatan Keuangan Perusahaan, (2) Dewan Direksi berpengaruh positif terhadap Tingkat Kesehatan Keuangan Perusahaan, (3) Komite Audit berpengaruh positif terhadap Tingkat Kesehatan Keuangan Perusahaan, (4) Ukuran Perusahaan berpengaruh positif terhadap Tingkat Kesehatan Keuangan Perusahaan, dan (5) Leverage, Dewan Direksi, Komite Audit dan Ukuran Perusahaan secara bersama-sama berpengaruh positif terhadap Tingkat Kesehatan Keuangan Perusahaan.
\end{abstract}

Kata Kunci: Tingkat Kesehatan Keuangan, Leverage, Dewan Direksi, Komite Audit, Ukuran Perusahaan 


\section{JURAL NOMINAL / VOLUME VIII NOMOR 1 / TAHUN 2019}

\section{INTRODUCTION}

The development of business stock trading in the capital market makes information about the condition of public companies (issuers) valuable for potential investors to invest funds. Quality of a company should be considered by looking at the ability of companies to choose an existing investment and be able to manage working capital to generate cash flow efficiently. Working effective capital turnover are affecting the financial condition of manufacturing company in several divisions. The financial is a benchmark aspect to judge the success in performance and important that affecting going concern of the company. Predicting corporate bankruptcies is needed because it is related to the sustainability and the funding of the company. Condition that occur has problems, such as: manufacturing industry retard the business because there is no stable in 2016, the manufacturing industry in Indonesia increasingly lagging behind compared to Vietnam. The development of the manufacturing industry in 2017 experienced a reduction in financial performance in the first, second and fourth quarter. It makes the condition of the level of health financial performance unstable.

One way to be aware of the company's financial condition by understand the level of health financial performance. According to Sutrisno (2007), in analyzing the financial statements of the entity in question, knowing in advance the ratio required for the analysis of financial ratios is important. It can be used to connect the elements contained in the interpretation annual financial statements. It is to show a satisfactory financial performance in the ongoing process of the working of a system. The result is using resources and funds owned allocating the company.

Many factors which increase the risk of bankruptcy such as the financial weakening of the next few years, mismanagement inside of the company, the decrease of purchasing rates and others (Azmi and Supardi: 2013). That shows that there are many reasons causing the company condition unpredictable. It is because they used the measurement that can predict the situation on the financial condition of the company.

Factors that can lead to changes in the company's financial condition such as loan. According to Toto (2008), a company that has a higher amount of debt can experiencing financial difficulties and can lead to the bankruptcy of the company. Because of that it is needed to increase the financial capital to develop the company. Even so, some of the debts have to be paid. The leverage ratio is used to measure a company's ability to meet all existing obligations. The company which has a lot of debt and has too many creditors may 
increase the potential for their failure to pay. It can result in a decreased level of financial performance health of the company compared to a company that only has a single creditor to minimize the possibility of default. Getting loans is needed by the company to be able to expand its business and can diversify the product to get profit.

The board of directors is one of the leaders of an entity whose existence is elected by the shareholders (investors) that have a primary duty to represent the interests of shareholders in managing an entity (Hadi, 2014). The board of directors is included in one of the mechanisms of good corporate governance which are required to reduce the level of agency problems between the owners of the company and the manager in the entity. The board of directors has an internal function within the entity to determine the short and long term policy in an entity. The number of boards of directors is great in a company can provide benefits to the enterprise, such as the network with various external parties.

The Audit Committee is one of the mechanisms in good corporate governance. According to FCGI, an audit committee can give insight about a financial problem especially in the fields of accounting, financial reporting and the independence of auditors, as well as the issues in the area of an entity's internal control. Thus, the members of the audit committee can hold meetings and also be able to exchange opinions as they have the experience of corporate governance and knowledge in finance different (Oktadella, 2011). It is possible because the member of audit committee can discuss the condition of financial in the company and can determine the effectiveness of the decision.

According to Fitdini (2009), the size of a company divided into three categories: large, medium, and small companies. The size of the company is also set out in Regulation of the Minister of Trade No. 46/M-Dag/Per/2009. The company that has a large total asset indicates that the company has reached a mature stage because its cash flow is stable and allows to have good prospects for a relatively long period. It indicates that the company is relatively stable and can generate profit compared with companies that have a small total asset (Rachmawati and Triatmoko, 2007).

Based on the background explained above, the author writes the title "The Effect of Leverage, Board of Directors, Audit Committee and Company Size on The Level of Health Financial Performance of The Company". 
JURAL NOMINAL / VOLUME VIII NOMOR 1 / TAHUN 2019

\section{RESEARCH METHOD}

\section{Research Design}

Based on the variables, this research is included in the causal research, where there are independent variables and dependent variables. Based on the type of data and analysis used, this research is included in the quantitative research, because this research uses many numbers, including in the process of data collection, data interpretation, and presentation of research results.

\section{Place and Time of the Research}

This research is conducted by taking the secondary data available on the internet. The official site is used as a place for data collection that is official website of the Indonesia Stock Exchange (www.idx.co.id). This research was conducted in October 2017 until March 2018.

\section{Population and Sample of Research}

The population in this research are manufacturing companies listed on the Indonesia Stock Exchange period 20142016. A purposive sampling method was used as a sampling method and 96 companies were selected as sample of research.

\section{Operational Variable Definition}

1) The Level of Health Financial Performance

This variable is measured by the Altman Z-Score. Altman was utilized a statistical technique called Discriminant Analysis to create a financial distress prediction model. It used to integrate the basic financial ratios as inputs to his model. The model formed by Alman for predicting a company's financial health is as follows:

$\mathrm{Zi}=0,717 \mathrm{X} 1+0.847 \mathrm{X} 2+3.107 \mathrm{X} 3+$ $0.998 \times 4+0.42 X 5$

Notes:

$\mathrm{X} 1=($ Current Assets-Current Debt $) /$

Total Assets

$\mathrm{X} 2=$ Retained Earnings $/$ Total Assets

$\mathrm{X} 3=$ Earnings Before Interest and Taxes / Total Assets

$\mathrm{X} 4=$ Book Value of Stock/ Book

Value Total Debt

$\mathrm{X} 5=$ Sales $/$ Total Assets

2) Leverage

Leverage in this research is using the Debt to Equity Ratio (DER), which is one ratio to measure the company's total liabilities to equity capital, the formula used is (Wuryanti and Khotimah, 2015):

$$
\text { DER }=\frac{\text { Total Liabilities }}{\text { Equity }}
$$

3) Board of Directors

In this research, the board of directors measured by the number of members of the board of directors in the 
company (Kusumawati and Riyanto, 2015).

4) Audit Committee

The audit committee in this research was measured using a scale interval (Utomo, 2014), the formula used is number of members audit committee in a company.

5) Company Size

In this research, the size of the companies used the assets of the company because its value is more stable. The formula used to determine the total assets in a company (Kashmir, 2014) is:

Company Size: Ln(Total Asset)

\section{Data Collection Technique}

The data used in this research is secondary data. This secondary data is obtained from the official website of the Indonesia Stock Exchange (www.idx.co.id).

\section{Data Analysis Technique}

The data analysis techniques were descriptive statistical analysis, classic assumption test, simple linear regression analysis, and multiple linear regression analysis.

\section{RESEARCH RESULTS AND DISCUSSION}

\section{Descriptive Statistical Analysis}

1) The Level of Health Financial
Performance

Data of the Level of Health Financial Performance shows that there are 8 samples $(3,20 \%)$ in the high category for the Level of Health Financial Performance, 97 samples $(38,80 \%)$ in the medium category and 145 samples $(58 \%)$ in the low category. Based on the results above show that the Level of Health Financial Performance for most manufacturing companies listed in BEI for the period 2014 to 2016 is in the low categories. This results can be looked at the histogram below.

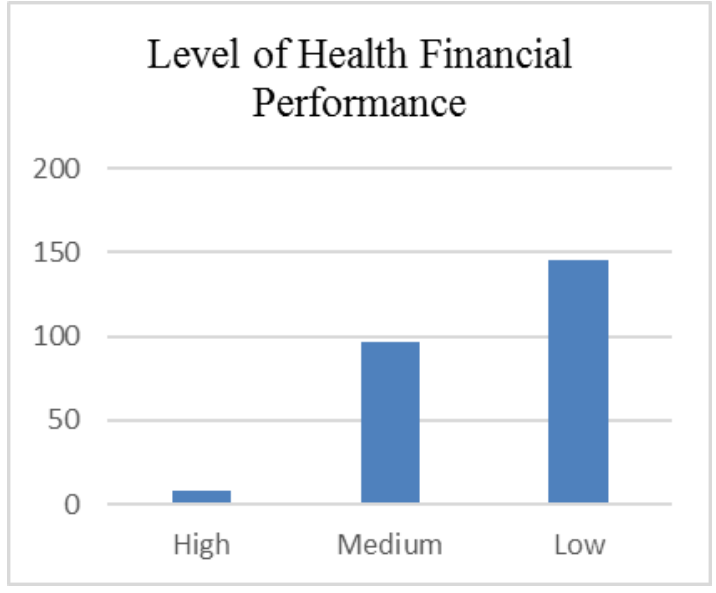

Figure 1. Data of the Level of Health Financial Performance.

2) Leverage

Data of Leverage shows that there are 62 samples $(24,80 \%)$ in the high category, 105 samples $(42,00 \%)$ in the medium category, and 83 samples $(33,20 \%)$ in the low category. Based on the results above show that Leverage for most manufacturing companies listed on the BEI for the period 2014 to 
2016 is in a medium category. This results can be looked at the histogram below.

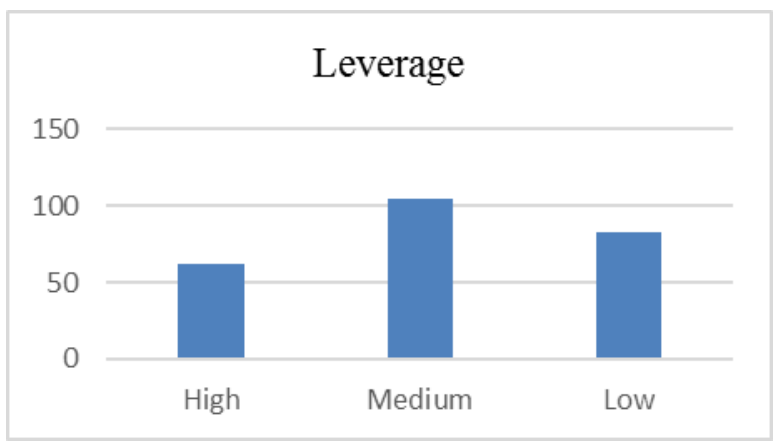

Figure 2. Data of Leverage

3) Board of Directors

Data of Board of Directors shows that are 5 samples $(2,00 \%)$ in the high category, 78 samples $(31,20 \%)$ in the medium category and 167 samples $(66,80 \%)$ in the low category. Based on the result above show that the number of boards of directors for most manufacturing companies listed on the BEI for the period 2014 to 2016 is in a low category. This results can be looked at the histogram below.

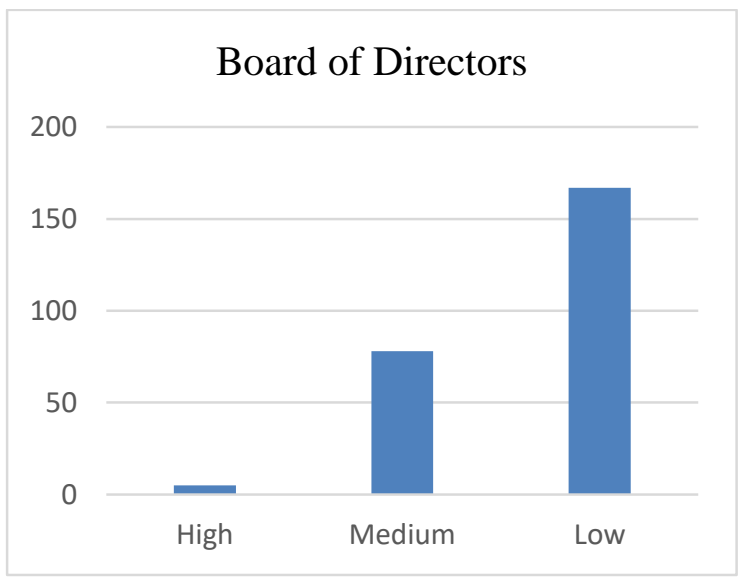

Figure 3. Data of Board of Directors
4) Audit Committee

Data of Audit Committee shows that are 8 samples $(3,2 \%)$ in the high category, 10 samples $(4,00 \%)$ in the medium category and 232 samples $(92,80 \%)$ in the low category. Based on the result above show that the number of audit committee for most manufacturing companies listed on the BEI for the period 2014 to 2016 is in a low category. This results can be looked at the histogram below.

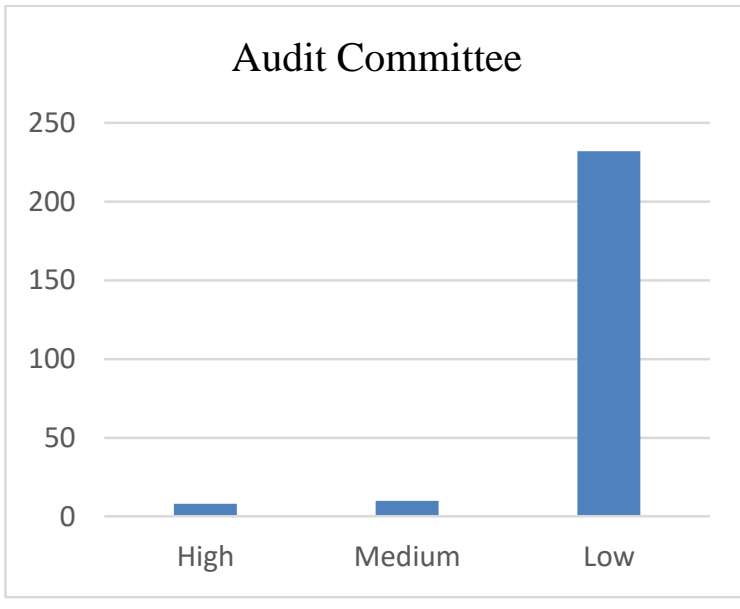

Figure 4. Data of Audit Committee

5) Company Size

Data of Audit Committee shows that are 25 samples $(10,00 \%)$ in the high category, 99 samples $(39,60 \%)$ in the medium category and 126 samples $(50,40 \%)$ in the low category. Based on the result above show that the number of company size for most manufacturing companies listed on the BEI for the period 2014 to 2016 is in a low category. This results can be looked at the histogram below. 


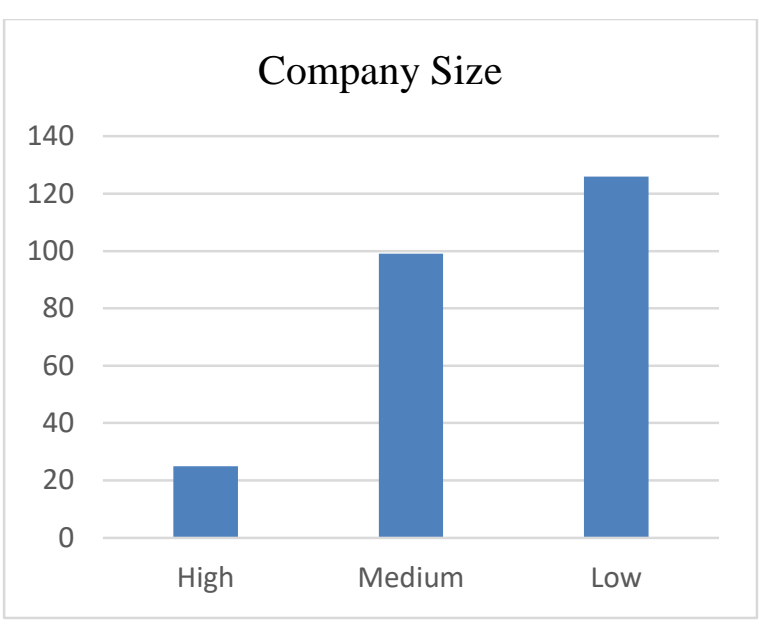

Figure 4. Data of Company Size

\section{Classic Assumption Test}

1) Normality Test

Based on Based on normality test, it shows that the significance value of Kolmogorov Smirnov is 0.185 . The value is greater than 0.05 , so it can be concluded that the data in this study is normally distributed.

\begin{tabular}{|l|c|c|}
\hline Variable & Asymp. Sig. & Conclusion \\
\hline Res_1 & 0.185 & Normal \\
\hline
\end{tabular}

Table 1. The Result of Normality Test

2) Multicollinearity Test

Based on multicollinearity test, it shows that the tolerance value of all independent variables is greater than 0.10 and the VIF value is less than 10 , so it can be concluded that the regression model that used in this study does not have multicoloniearity.

\begin{tabular}{|c|c|c|}
\hline Variables & Tolerance & VIF \\
\hline $\mathrm{X}_{1}$ & 0,967 & 1,034 \\
\hline $\mathrm{X}_{2}$ & 0,708 & 1,413 \\
\hline $\mathrm{X}_{3}$ & 0,863 & 1,159 \\
\hline $\mathrm{X}_{4}$ & 0,672 & 1,487 \\
\hline
\end{tabular}

Table 2. The Result of Multicollinearity Test

\section{3) Autocorrelation Test}

Based on autocorrelation test, it can be seen that the coefficient of DurbinWatson has a value 0.831 and above of $\mathrm{dU}$ that has value of 1,809 . This shows that the regression model does not contain autocorrelation problem

\begin{tabular}{|l|l|c|}
\hline \multicolumn{1}{|c|}{$\begin{array}{c}\text { Variable } \\
\text { Dependent }\end{array}$} & $\begin{array}{c}\text { Durbin- } \\
\text { Watson }\end{array}$ & \multicolumn{1}{c|}{} \\
\hline $\begin{array}{l}\text { The Level of Health } \\
\text { Financial } \\
\text { Performance }\end{array}$ & 1,831 & 1,809 \\
\hline
\end{tabular}

Table 3. The Result of Autocorrelation Test

4) Heteroscedasticity Test

Based on heteroscedasticity test, it can be seen that all independent variables in this research not related significantly, there is not a clear pattern and the points spread over and below number 0 that located on the $\mathrm{Y}$ axis This shows that the regression model does not contain heteroscedasticity problem. 
Table 4. The Result of Heteroscedasticity Test

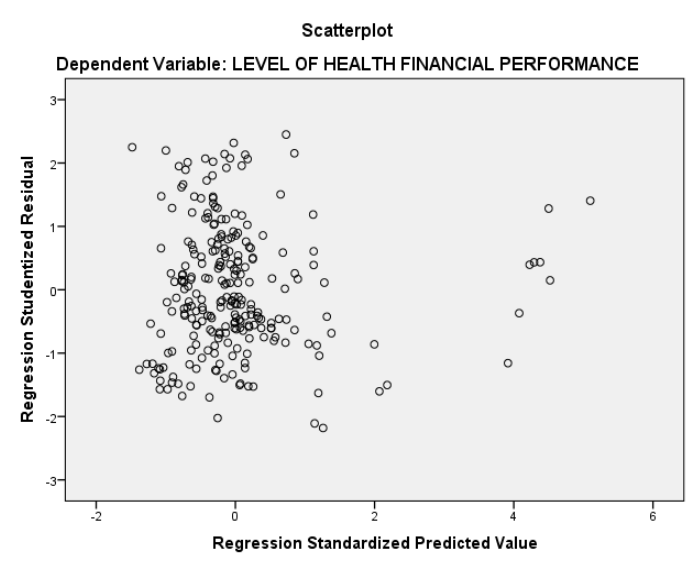

5) Linearity Test

Based on linearity test, it shows that the value of $\mathrm{c}^{2}$ count is smaller than $\mathrm{c}^{2}$ table, it can be concluded that this regression model is linear.

\begin{tabular}{cccc}
\hline Model & $\mathbf{R}^{2}$ & $\mathbf{C}^{2}$ count & $\mathbf{C}^{2}$ table \\
\hline 1 & 0.003 & 0.75 & 287.882
\end{tabular}

Table 5 . The Result of Linearity Tes

\section{Hypothesis Test}

1) First Hypothesis Test

The summary of first hypothesis test results can be seen in the following table.

\begin{tabular}{lc}
\hline \multicolumn{1}{c}{ Information } & Value \\
\hline Constant & 0.930 \\
\hline Coefficient & 0.271 \\
\hline $\mathbf{r}^{\mathbf{2}}$ & 0.043 \\
\hline $\mathbf{t}_{\text {count }}$ & 3.329 \\
\hline $\begin{array}{l}\text { Table 4. The Result of } \\
\text { Heteroscedasticity } \\
\text { Test }\end{array}$ \\
$\begin{array}{l}\mathbf{t}_{\text {table }} \\
\text { Sig. }\end{array}$ \\
\begin{tabular}{l} 
Table 6. The Result of First Hypothesis Test \\
\multicolumn{2}{c}{ Based on table 6, the equation for }
\end{tabular}
\end{tabular}

simple linear regression in the first hypothesis test is as follows.

Level of Health Financial Performance $=$

$$
0,930+0,271 \text { Leverage }
$$

The value of regression coefficient is 0.271 and the value of $t_{\text {count }}$ is 3.329 which greater than $t_{\text {table }}$ of 1.969. The significance value is 0.001 , smaller than the predefined significance value of 0.05 . This shows that Leverage has a positive effect on the Level of Health Financial Performance.

Increase in leverage indicates that the company is able to optimize the company's financial performance be able to manage capital and can develop the company so that it can convince investors to invest (Eliu, 2014). The number of investors who invest in the company can be a stimulus factor for improving corporate financial performance because, with large capital, companies can diversify products that generate large profits. This encourages investor confidence in investing capital and increasing investment in the company. Information about leverage can affect the value of the company that shows the signal that the level of health financial performance in good and stable can provide high profits (Wuryanti and Khotimah, 2015).

2) Second Hypothesis Test

The summary of second hypothesis test results can be seen in the following table. 


\begin{tabular}{ll}
\hline \multicolumn{1}{c}{ Information } & Value \\
\hline Constant & 0.692 \\
\hline Coefficient & 0.098 \\
\hline $\mathrm{r}^{2}$ & 0.110 \\
\hline $\mathrm{t}_{\text {count }}$ & 5.533 \\
\hline $\mathrm{t}_{\text {table }}$ & 1.969 \\
\hline Sig. & 0.000 \\
\hline
\end{tabular}

Table 7. The Result of Second Hypothesis Test

Based on table 7, the equation for simple linear regression in the second hypothesis test is as follows.

Level of Health Financial

Performance $=0,692+0,098$ Board

of Directors

The value of regression coefficient is 0.098 and the value of $t_{\text {count }}$ is 5.533 which greater than $t_{\text {table }}$ of 1.969 . The significance value is 0.000 , smaller than the predefined significance value of 0.05 . This shows that Board of Directors has a positive effect on the Level of Health Financial Performance.

In the Law of Incorporated Company stated that the board of directors has the right to represent external interest as well as within the company. The number of boards of directors affect the accuracy of corporate decision making so that the role of the board of directors is important to manage the resources (Sukandar, 2014). Increasingly effective internal relationship need an increasing number of boards of directors (Wuryanti and Khotimah, 2015). The large number of boards of directors can strengthen the monitoring and internal implementation of the company so that financial condition can be maintained with a stable.

3) Third Hypothesis Test

The summary of third hypothesis test results can be seen in the following table.

\begin{tabular}{ll}
\hline \multicolumn{1}{c}{ Information } & Value \\
\hline Constant & 0.287 \\
\hline Coefficient & 0.265 \\
\hline $\mathrm{r}^{2}$ & 0.240 \\
\hline $\mathrm{t}_{\text {count }}$ & 8.853 \\
\hline $\mathrm{t}_{\text {table }}$ & 1.969 \\
\hline Sig. & 0.000 \\
\hline
\end{tabular}

Table 8. The Result of Third Hypothesis Test

Based on table 8 , the equation for simple linear regression in the third hypothesis test is as follows.

Level of Health Financial

Performance $=0,287+0,265$ Audit

Committee

The value of regression coefficient is 0.265 and the value of $t_{\text {count }}$ is 8.853 which greater than $\mathrm{t}_{\text {table }}$ of 1.969 . The significance value is 0.000 , smaller than the predefined significance value of 0.05 . This shows that Audit Committee has a positive effect on the Level of Health Financial Performance.

Audit committees within the company have a role to supervising financial statements and external audits, observing internal control systems and functioning to assist boards of 
commissioners to improve the quality of financial statements and controls that can reduce the possibility of irregularities (Istiqomah, 2015). This has led to the existence of an audit committee important to the company to create more conducive and disciplined financial circumstances. Functioning of the audit committee effectively makes control of the company will be effective so that the agency conflict that occurs due to management's desire to improve its prosperity can be minimized (Melawati et al, 2011).

\section{4) Fourth Hypothesis Test}

The summary of fourth hypothesis test results can be seen in the following table.

\begin{tabular}{lc}
\hline \multicolumn{1}{c}{ Information } & Value \\
\hline Constant & $-1,045$ \\
\hline Coefficient & 0.077 \\
\hline $\mathrm{r}^{2}$ & 0.036 \\
\hline $\mathrm{t}_{\text {count }}$ & 3.046 \\
\hline $\mathrm{t}_{\text {table }}$ & 1.969 \\
\hline Sig. & 0.003 \\
\hline
\end{tabular}

Table 9. The Result of Fourth Hypothesis Test

Based on table 9, the equation for simple linear regression in the fourth hypothesis test is as follows.

Level of Health Financial

Performance $=-1,045+0,077$

Company Size

The value of regression coefficient is 0.077 and the value of $t_{\text {count }}$ is 3.046 which greater than $t_{\text {table }}$ of 1.969 . The significance value is 0.003 , smaller than the predefined significance value of 0.05 . This shows that Company Size has a positive effect on the Level of Health Financial Performance.

The large company can show the company's ability to pay off future corporate liabilities, it can be a benchmark for the company to avoid the company's financial problems (Putri, 2015). This indicates that larger companies are more promising for good performance. Good performance is also supported by profitability opportunities that can be increased, that it can convince external parties who will invest their capital because companies that have increased assets have more access to sources of funds, both to the capital market or banking. This company has a higher chance of winning the competition and staying in the industry (Syahida et al., 2017). It can provide a positive signal for investors that can increase the value the company.

5) Fifth Hypothesis Test

The summary of fifth hypothesis test results can be seen in the following table.

\begin{tabular}{lc}
\hline \multicolumn{1}{c}{ Information } & Value \\
\hline Constant & 1.229 \\
\hline Coefficient $\left(\mathrm{X}_{1}\right)$ & 0.171 \\
\hline Coefficient $\left(\mathrm{X}_{2}\right)$ & 0.075 \\
\hline Coefficient $\left(\mathrm{X}_{3}\right)$ & 0.241 \\
\hline Coefficient $\left(\mathrm{X}_{4}\right)$ & -0.048 \\
\hline $\mathrm{r}^{2}$ & 0.307 \\
\hline $\mathrm{F}_{\text {count }}$ & 27.099 \\
\hline $\mathrm{F}_{\text {table }}$ & 2.41 \\
\hline Sig. & 0.000 \\
\hline
\end{tabular}


Table 10. The Result of Fifth Hypothesis Test

Based on table 10, the equation for multipler regression in the fifth hypothesis test is as follows.

Financial Health Level $=1,229+$

0,171Leverage $+0,075$ Board of

Directors + 0,241Audit Committee -

0,048Company Size

The coefficient of determination value is 0.307 or $30.7 \%$. This value indicates that $30.7 \%$ of variance that happened on the Level of Health Financial Performance are effected by Leverage, Board of Directors, Audit Committee and Company Size variables, while $69,30 \%$ is influenced by other factors.

The value of $F_{\text {count }}$ is 27.099 which greater than $F_{\text {table }}$ of 2.41 . The significance value is 0.000 , smaller than the predefined significance value of 0.05 . Based on the results of hypothesis test, it shows that Leverage, Board of Directors, Audit Committee and Company Size simultaneously has a effect on the Level of Health Financial Performance.

\section{CONCLUSION AND SUGGESTION}

\section{Conclusion}

Based on the results of research and the discussion in the previous chapter, it can be concluded as follows.
1) Leverage has a positive effect on the Level of Health Financial Performance. This show that increased leverage can affect the Level of Health Financial Performance. It occurs because the company is able to efficiently operate resources from external parties. Therefore, investors who know this positive signal will be more confident to invest the capital because to know the company's financial performance goes well.

2) Board of directors has positive effect on the Level of Health Financial Performance. The large boards of directors are affected by the accuracy of corporate decision making so that its role is important to manage the direction of policy and strategy resources within the company. The placement of the board of directors in certain areas focused in order financial performance can increase and the level of health financial performance of the company remains stable.

3) Audit Committee has positive effect the Level of Health Financial Performance. The audit committee has a role in overseeing financial statements and external audits, and internal control systems to reduce 
opportunities for deviations. A lot of Audit Committee membership can affect the financial performance of the company because it will be well supervised so that it can improve the financial stability of the company through such supervision.

4) Company Size has positive effects on the Level of Health Financial Performance. This indicates that large companies are showing positive signals for investors that the company's performance can implement effectively and efficiently. This company indicates that the capital invested caused rotation of funds that can be managed efficiently and improve the performance which can affect the improvement of financial stability.

5) Leverage, Board of Directors, Audit Committee and Company Size simultaneously has a positive effect on the Level of Health Financial Performance because Leverage, Board of Directors, Audit Committee and Company Size are the factors that affect the Level of Health Financial Performance.

\section{Suggestion}

Based on the results of research and limitations of this study, the researchers can provide suggestions as follows.

1) Company

Companies should notice internal and external factors of management to makes the company's stable and performance of company can be maintained, continue to increase the leverage and assets that makes financial performance can be proceed stably, and be able to improve its performance.

2) Investors

Investors should understand relevant informations, both internal and external factors that are available in the capital market through published corporate financial statements. Investors should be aware to positive signals from the company when the financial statements are published, so that investors can determine which companies that have the potential to distribute the devidend.

3) Government

Regulations within the government should provide opportunities for companies in developing their business for the sustainability of the company because of the existence of the company becoming one of the 
economic state pillars.

4) Advanced Research

Further research is suggested to investigate the other factors that may determine the Level of Health Financial Performance, such as another good corporate governance.

\section{REFERENCE}

Azmi, Nurul and Supardi. (2013). Faktorfaktor yang Mempengaruhi Ketepatan Waktu Pelaporan Keuangan. Jurnal Accounting Politeknik Sekayu, ISSN: 24072184.

Eliu, Viggo. (2014). Pengaruh Financial Leverage dan Firm Growth Terhadap Financial Distress. Jurnal FINESTA, Vol. 2 No. 2.

Fitdini, Juanda Eka. (2009). Hubungan Struktur Kepemilikan, Ukuran Dewan, Dewan Komisaris Independen, Ukuran Perusahaan, Leverage, dan Likuiditas Dengan Kondisi Financial Distress. Skripsi, dipublikasikan. Universitas Diponegoro.

Hadi, S. (2014). Mekanisme Corporate Governance, Likuiditas, Leverage, dan Operating Capacity pada Perusahaan yang Mengalami Financial Distress. Skripsi, dipublikasikan. STIESIA Surabaya.

Istiqomah, Lia. (2015). Pengaruh Good Corporate Governance Terhadap Kinerja Perusahaan. Naskah Publikasi. Universitas Muhammadiyah Surakarta.

Kasmir. (2014). Analisis Laporan Keuangan. Edisi 1. Jakarta: Raja Grafindo Persada.
Melawati, Siti Nurlaela dan Wahyuningsih, Endang Masitoh. (2016). Pengaruh Good Corporate Governance, CSR dan Ukuran Perusahaan Terhadap Kinerja Perusahaan. Journal of Economics and Economic Education, Vol. 4 No. 2.

Oktadella, Dewanti. (2011). Analisis Corporate Governance Terhadap Integritas Laporan Keuangan. Skripsi, dipublikasikan. Universitas Diponegoro Semarang.

Putri, T.Y. (2015). Pengaruh Likuiditas, Leverage, Pertumbuhan Penjualan dan Perputaran Modal Kerja Terhadap Profitabilitas. Skripsi. Universitas Pasundan.

Rachmawati, Andri dan Hanung, Triatmoko. (2007). Analisis FaktorFaktor yang Mempengaruhi Kualitas Laba dan Nilai Perusahaan. Simposium Nasional Akuntansi $X$ Makassar.

Sukandar, Pangky Pradana. (2014). Pengaruh Ukuran Dewan Direksi dan Dewan Komisaris Serta Ukuran Perusahaan Terhadap Kinerja Keuangan Perusahaan. Skripsi. Universitas Diponegoro.

Sutrisno. (2007). Manajemen Keuangan Teori, Konsep dan Aplikasi. Yogyakarta: EKONISA

Toto, Prihadi. (2008). Deteksi Cepat Kondisi Keuangan: 7 Analisis Rasio. Cetakan 1. Jakarta: PPM.

Utomo, Arsanto Teguh. (2014). Pengaruh Mekanisme Good Corporate Governance Terhadap Kinerja Keuangan. Skripsi. Universitas Diponegoro.

Wuryanti, K dan Khotimah, Siti. (2015). Pengaruh Good Corporate 
JURAL NOMINAL / VOLUME VIII NOMOR 1 / TAHUN 2019

Governance, Leverage dan Corporate Social Responsibility

Terhadap Kinerja Keuangan.

EKOBIS, Vol. 1 6, No. 1. 